DOI: 10.33310/2518-7813-2019-66-3-108-113

УДК 378.147.88: 811.111

\author{
Iryna KAMINSKA \\ $P h D$ in Education, \\ Associate Professor of foreign languages \\ State University of Telecommunications, Kyiv, Ukraine \\ e-mail: irina717@ukr.net
}

\title{
ASPECTS OF USING DICTIONARIES IN THE PROCESS OF ACADEMIC ENGLISH TEACHING AND ACQUISITION
}

In the article, the linguistic characteristics of academic English are considered. The vocabulary and genres of academic English are addressed. The types of dictionaries currently available to university students are defined. It is established that academic language is linguistically diverse across discourses, genres, and disciplines. The variations in academic language demand a range of linguistic skills from students. Learners therefore need access to language tools, notably dictionaries, in their studies.

The analysis of the respective dictionaries demonstrates that none of them is suitable for academic English acquisition. They are too comprehensive in coverage, contain linguistically demanding definitions and offer little encoding information. A need for dictionaries that would meet the students' demands is defined.

Keywords: academic English, dictionary, language acquisition, spoken and written genres, language teaching.

Problem statement. Over the past three decades, academic English has attracted considerable attention from researchers. A great deal of the research has been driven by pedagogical motives, which are closely related to the increase in the number of students at universities acquiring English for academic purposes.

The fact that academic English is different from general English means that students face several difficulties because they need to learn how to use a language they know in new ways. Consequently, disciplines like English for Academic Purposes and English for Specific Purposes have started to play a more prominent role in higher education in the last few decades.

The focus of students is on the contents of their study. As a result, students are more likely to use language tools which can help them with addressing language problems at the moment of encountering them. One of the most important language tools of this kind is a dictionary.

Literature overview. Corpora and corpus techniques have played a key role in the research into academic English. The scholar Kosem, I[6, p. 357] points out corpora have proved useful in determining the features of academic English, and have stimulated research into register and genre. Researchers Benesch, S., Dudley-Evans, T., Flowerder, J., John, M., Peacock, M. remark that corpora have also helped to revive some earlier approaches, such as rhetorical analysis and pragmatic analysis. Corpus techniques have also helped researchers to identify not only the differences between different genres of academic English [5], but also the differences between academic English and general English [4]. Vocabulary and its acquisition has always been one of the main focus areas of research in academic English McCarthy, M., Nation, P., Schmitt, N., Waring, R. The use of dictionaries in the process of academic English teaching and acquisition, as well as the types thereof, are analysed in the works by Benson, M., Haill, R., Lea, D., Nesi, H., Rundell, M., Svensen, B., Thompson, P. Basing on the analysis of the aforementioned works, it is established that the differences between academic English and general English are yet to be fully acknowledged by lexicographers. This problem is exacerbated by the unclear status of students as dictionary users since there is a great deal of research in dictionary application that sees students as subjects, but very few studies actually examine the dictionary use of students. As a result, not much is known about which dictionaries students utilize, and how they use or misuse them.

The aim of the article is to take a closer look at the linguistic characteristics of academic English, and give an overview of research into the registers, genres and vocabulary of academic English. The focus then shifts to the dictionaries currently available to students, and their suitability for the needs of students is evaluated in terms of their representative coverage of academic English. It aims to establish why there is a need for a dictionary of academic English by looking at the characteristics of academic English, and by discussing why existing dictionaries fail to reflect these characteristics.

A great number of monolingual and bilingual dictionaries have been produced, both in terms of number and variety. This is especially true of advanced learners' dictionaries, which have been the source of some important lexicographic innovations. Thus, university students have been provided with valuable tools to tackle English language-related 
problems during their studies, but not specifically for academic English.

Research into academic English has largely focussed on written academic discourse. Scholars mainly study genres produced by academics, and the genre of the research article in particular: Charles, M., Coxhead, A., Flowerdew, J., Groom, N., Hewings, A., Hyland, K., Koutsantoni, D., Lewin, B., Schmitt, N., Silver, M., Stotesbury, H., Swales, J., Tucker, P.

Some of the above-mentioned studies have used corpora that contained other genres in addition to research articles, for instance books and book reviews, but all of these genres, while read by students, are primarily targeted at other academics. Researchers have therefore become interested in genres that specifically target students, arguing that the language in those genres is what students will encounter and need help with [2].

British researches of academic written English corpus identify thirteen genre families: case study, literature review, critique, methodology recount, design specification, narrative recount, empathy writing, problem question, essay, proposal, exercise, research report, explanation. Each genre family contains several genres, the total number of genres being fifty. The main distinguishing characteristic is the discipline the genre is found in. For example, the genre family "design specification" contains the following genres that are predominantly found in Computer Science and Engineering: application design, building design, database design, game design, label design, product design, system design, and website design.

Written academic genres are also internally complex. They contain different sub-genres. Some of the genre families and genres can be either a genre or a sub-genre, for instance literature review can be a complete text, or it can be only a part of a text, such as a book or an article. Implementing a comprehensive attempt to describe spoken genres in academic discourse, researches identified several genres and grouped them into classroom events, notably small lectures, large lectures, discussion sections, lab sections, seminars, student presentations, and nonclassroom events, namely, advising sessions, colloquia, dissertation defences, interviews, meetings, office hours, service encounters, study groups, tours. Apart from studying individual genres, scholars investigate differences and similarities between different genres. Studies of this type can be divided into three groups: studies that compare genres of the same discourse, studies that compare spoken genres with written genres, and studies that compare characteristics of a genre or genres in different disciplines. Multi-dimensional studies that involved analysis of spoken academic registers have shown that "all spoken registers are similar in their typical linguistic characteristics" [2, p. 223]. The researcher makes a comprehensive comparison between spoken and written academic registers, and concludes that "spoken registers are systematically different from written registers, with respect to a wide range of vocabulary characteristics and lexico-grammatical features" [2, p. 177). One of the few registers where some similarities are found is student management registers, namely spoken classroom management and written course management.

Another area where multi-dimensional analysis has provided useful insights is disciplinary variation among academic registers. Biber, D. compares five discipline categories, namely, Business, Engineering, Humanities, Natural Science, and Social Science and finds that there are similarities between Social Science and Humanities, and between Business and Engineering, but remarks that these two groups of disciplines differ significantly in the use of several linguistic features. Natural Science disciplines are found to be somewhere in between, being similar to both groups, but with these similarities lying in different linguistic features.

The aforesaid enables us to drive to the conclusion that academic language is linguistically very diverse across discourses, genres, and disciplines. Most significant differences in the use of academic language are found between spoken genres and written genres, between student writing and expert writing, and between certain disciplines. One of the rare similarities found is the one across all spoken academic genres.

Within the scope of the article it is deemed necessary to to elaborate the issue of Academic English compared to general English. Most studies of academic language have focussed on particular registers, genres, and disciplines. Those studies have not considered academic language as a whole, and compared its linguistic characteristics with other general registers of English. Especially noteworthy are the findings by Biber, D.:

a) nouns, adjectives, and prepositions are very frequent in academic writing, more than in the other three registers;

b) grammatical features especially characteristic of academic writing are, for example, nominalizations, a stance noun with an "ofphrase", noun phrases with modifiers, thatclauses and relative clauses with the relative pronoun "which";

c) several grammatical features are frequent only in academic writing, for instance verbs with inanimate subjects, "that" or "those" with an "of-phrase", quantifier "each", coordination tag [2].

The differences between registers are likely to present difficulties to students. Thus the grammatical 
features that are frequent in academic language, but infrequent in other registers may be problematic due to students' lack of familiarity with their use and functions. On the other hand, learners may overuse some grammatical features that are not common in academic language.

Summing up, we can draw to the implication that Academic English is far from homogenous. Both spoken academic discourse and written academic discourse consist of many genres and sub-genres. The genres and sub-genres are very varied in terms of their linguistic characteristics. The main differences between the genres are observed at mode, disciplinary and proficiency levels. The variations in academic language demand a range of linguistic skills from students. Several grammatical features could seriously impede comprehension or production of academic texts. Comprehension of an academic text also becomes problematic when students encounter unfamiliar words. The aforementioned observations determine the focus of vocabulary studies, which are discussed next.

Vocabulary and its acquisition has always been one of the main focus areas of research in academic English by scholars McCarthy, M., Nation, P., Schmitt, N., Waring, R. A large scope of studies is based on the notion that students need to understand $95 \%$ of the words in the text to gain reasonable comprehension. It is expected that students attempting to achieve this comprehension threshold will know high frequency words before starting their studies. Scholars have therefore concentrated on studying academic vocabulary, namely vocabulary which "is common to a wide range of academic texts and not so common in non-academic texts" [7, p. 189]. This has led to the production of many different corpus-based wordlists.

Coxhead, A and Nation, P. divide the English lexicon into four groups: high frequency words, academic vocabulary, technical vocabulary, which is different for each domain, and low frequency words [3]. High frequency words comprise 2.000 word families and cover around $80 \%$ of words in an academic text [7]. According to Coxhead, A and Nation, P., technical vocabulary does not exceed 1,000 words in any individual subject area, and represents 5\% of words in an academic text. Low frequency words, representing the final $5 \%$ of the words in an academic text, may be text-specific or occur only once or twice in a general corpus. The importance of low frequency words for students is considered negligible, as knowledge of the other three groups is expected to ensure reasonable comprehension of an academic text. Academic vocabulary covering approximately $10 \%$ of words in an academic text is considered key to students' success in understanding academic language [4].
There is little doubt that wordlists of academic words have some pedagogic value. Due to the fact that wordlists do not provide any information about the meaning, word class and phraseology of the words they contain, they are of little value to students. Wordlists can thus be considered merely a point of departure for teachers dealing with English for academic purpose who have limited time to try and teach students how to understand and use academic language. One of the major weaknesses of all the different types of wordlists (academic, productively-oriented, discipline-specific academic and collocation wordlists) is that the methodology used to create them is aimed at excluding certain words, normally high frequency words and less frequent, technical words. Omission of high frequency words is based on the assumption that students know those words already. Considering what knowing a word entails knowing all its meanings, collocations, patterns, synonyms, it is highly unlikely any student will possess such knowledge. It is more likely that students will know core meanings and patterns of the words. Consequently, if a word has a different meaning or different distribution of meanings in academic English, it will probably present difficulties to students.

Academic English is linguistically very complex, and this is evident in its vocabulary and phraseology. Differences in linguistic features are found not only between written academic discourse and spoken academic discourse in general, but also between written and spoken genres. Linguistic variation is also manifested at discipline level. Words are not only used differently, they are often used in divergent functions and patterns. Academic English is different from general English in terms of vocabulary and grammar. Certain words and grammatical features are much more frequent in written academic English than in general English, and are often considered characteristic of academic English due to their frequency in academic English, and relative infrequency in general English.

Students will therefore need access to language tools to help them during their studies. One such important tool is the dictionary. Students can choose from a wide range of dictionaries. However, they might be of no value to the learners as far as problems of academic English are concerned.

There are numerous monolingual English dictionaries at disposal. Each dictionary for students selects its own set of features, which are designed specifically for students. Studies show that students also use other types of dictionaries, such as technical and bilingual dictionaries, quite often. These types of dictionaries can be regarded as secondary lexicographic resources, as they present an addition to general-purpose dictionaries rather than an alternative. 
Technical dictionaries deal with the vocabulary of one or more disciplines. They are most often produced by term biologists or subject experts. Technical dictionaries usually cover only a few thousand words. Most of the entries are nouns. Such dictionaries differ from general dictionaries not only in coverage, but also in the manner of defining the words. Technical dictionaries are virtually devoid of information needed for encoding. They do, however, often provide illustrations, which can be effectively used for both decoding and encoding purposes. Technical dictionaries have an educational function as well. The authors of technical dictionaries determine their target users by considering their level of subject expertise, rather than their language proficiency. Students are named as the target readership particularly often.

Thesauri are based on the meaning of the words, tools and thus very useful for students who have to produce a great deal of written material during their studies. Using a thesaurus requires a relatively high level of language proficiency; the user needs to know the meanings of the looked up words and of all the synonyms, their grammatical and collocation characteristics, and the differences in meaning usage between the looked-up word and any of its synonyms. Without this knowledge, the user may need to look up the words and synonyms in a dictionary to obtain this information.

There are also dictionaries available that deal with a specific part of the lexicon or that focus on particular kinds of encoding information. These include dictionaries of idioms, dictionaries of phrasal verbs, dictionaries of collocations, production dictionaries and pictorial dictionaries. Rundell, M. describes production dictionaries as "a conceptually organized reference resource designed specifically to meet the encoding needs of learners. It is organized around what cognitive psychologists would call "basic-level concepts", and the look-up process essentially involves deciding on a broad meaning area, selecting the keywords to which it is related, and then browsing and comparing sets of near synonyms" [8 pp. 327-328]. The use of this resource requires not only advanced language skills but also advanced dictionary skills.

It is deemed necessary to take a closer look at some of the main macrostructural and microslructural features of three types of dictionaries used by students: general-purpose dictionaries, learners' dictionaries and dictionaries for university student. Corpus-based dictionaries have now become the norm in lexicography. Lexicographers use corpora to obtain information on the frequency of words and phrases, to discover their meanings, and to find examples of authentic usage. All three types of dictionaries are based on corpora of general English. And although academic texts are found in any general language cor- pora, they are often incomplete, and suffer from a lack of representativeness [9]. As a result, academic words and academic word meanings have a less prominent role.

The coverage in general-purpose dictionaries is very comprehensive. This can be positive for students as technical terms and meanings are included. However, the negative aspect is that the dictionaries include words and meanings for many non-academic communications which can hinder navigation through the entries. Definitions in general-purpose dictionaries are relatively short and contain rarer words, and therefore require high language proficiency. This is likely to present problems to students whose vocabulary knowledge is not at the level expected from the target users of these dictionaries.

Much less challenging are the definitions in learners' dictionaries, which often use a restricted defining vocabulary. The coverage in learners' dictionaries is significantly reduced, when compared with general general-purpose dictionaries. The focus is on more frequent words and meanings. Rarer words and meanings are excluded, which is beneficial to students. Exclusion of many technical terms and meanings is much more problematic as students are likely to encounter terminology frequently during their studies. Furthermore, as frequency is likely to be a key factor in deciding which word or sense to exclude, many academic uses of the words may not be covered by a learners' dictionary due to the nonacademic nature of most of the corpus data. Learners' dictionaries tend to provide plenty of examples, using them to not only support the definition thus providing additional decoding information, but to demonstrate the usage and phraseology of the word.

The coverage in dictionaries for university students resembles the coverage in learners' dictionaries, meaning that many rarer words and technical words are excluded. In comparison to definitions in general-purpose dictionaries, definitions in dictionaries for university students are left almost unchanged. Whenever a change is made, definitions usually become shorter. Students are therefore seen as having the same language competence, if not even higher, than the users of general-purpose dictionaries.

The above analysis of a few core dictionary features has shown that none of the three types of dictionaries is suitable for students. They are too comprehensive in coverage, contain linguistically demanding definitions and offer little encoding information. Learners' dictionaries are much more userfriendly, offering less complex definitions and a great deal of encoding information. Shortcomings of learners' dictionaries are small coverage, especially of terminology. Dictionaries for university students are no more than a spin-off of general-purpose dictionaries. 
It often seems that no significant lexicographic effort has been put into the creation of the dictionary for students. The main problem of all three types of dictionaries is that they are based on corpora of general English, rather than academic English. As a result, the entries do not reflect the semantic and lexicogrammatical properties of words as used in academic English. General senses of the words are given more prominence than academic senses. Currently no dictionary on the market can offer a comprehensive description of academic English.

Conclusions and implications. Students often rely on a dictionary for help with the language they are encountering during their studies. The dictionaries mainly used are general dictionaries and learners' dictionaries. But none of these types of dictionaries are very helpful as they reflect general English rather than academic English. Lexicographers and researchers have pointed to the shortcomings of existing dictionaries in terms of student needs, but very few have called for a completely new dictionary for students. Instead, most studies have provided suggestions for improving existing dictionaries, or offered advice on which existing dictionaries are more suitable for students. There is clearly a demand for a dictionary that would meet the students' needs. Such a dictionary should incorporate research on academic English. Most importantly, it needs to be based on a corpus of academic language, and not general language.

\section{References}

1. Biber, D., Conrad, S. (1999). Lexical bundles in conversation and academic prose. In Hasselgard, H. and Oksefjell, S. (eds.), Out of Corpora: Studies in Honour of Stig Johansson (pp. 181-189). Amsterdam: Rodopi.

2. Biber, D. (2006). University Language: A corpus-based study of spoken and written registers. Amsterdam: John Benjamins.

3. Coxhead, A., Nation, P. (2001). The specialised vocabulary of English for Academic Purposes. In Flowerdew, J. and Peacock, M. (eds.), Research Perspectives on English for Academic Purposes. Cambridge: Cambridge University Press.

4. Hyland, K., Tse, P. (2007). Is there an "Academic Vocabulary"? TESOL Quarterly, N 41 (pp. 235-253). Canada: Wiley Online Library.

5. Hyland, K. (1999). Talking to Students: Metadiscourse in introductory course books. English for Specific Purposes, N 18, Issue 1, pp. 3-26.

6. Kosem, I. (2007). Issues in creating a corpus for EAP pedagogy and research. Journal of English for Academic Purposes, N 6, Issue 4, pp. 356-373.

7. Nation, I. (2001). Learning Vocabulary in Another Language. Cambridge: Cambridge University Press.

8. Rundell, M. (1998). Recent Trends in English Pedagogical Lexicography. International Journal of Lexicography, N 11, Issue 4, pp. 315-342.

9. Thompson, P. (2006). Assessing the contribution of corpora to EAP practice. In Kantaridou, Z., Papadopoulou, I. and Mahili, I. (eds.) Motivation in learning language for specific and academic purposes. Macedonia: University of Macedonia.

\section{Ирина Каминская. Аспекты использования словарей в процессе преподавания и овладения англоязычной академической речью}

В статье рассматриваются лингвистические характеристики англоязычной академической речи. Охарактеризованы жанры и словарный состав англоязычной академической речи. Проанализированы типы словарей, используемые студентами университетов. Установлено, что англоязычная академическая речь характеризуется лингвистическим разнообразием, обусловленным ее принадлежностью к разным сферам дискурса, жанрам и учебным дисциплинам. Такие различия в англоязычной академической речи обуславливают потребность формирования у студентов широкого диапазона языковых умений и навыков. Следовательно, учащимся необходим лингвистический инструментарий, а именно словари, для обеспечения эффективности учебного процесса.

Анализ используемых словарей выявил, что ни один из них не соответствует в полной мере требованиям, предъявляемым процессом обучения англоязычной академической речи. Для словарей характерен избыточный охват значений, лингвистически сложные определения и недостаток вводной информации. В статье указывается на необходимость создания словарей, отвечающих потребностям студентов.

Ключевые слова: англоязычная академическая речь, словарь, language, изучение языка, жанры устной и письменной речи, обучение языку.

Ірина Камінська. Аспекти застосування словників у процесі навчання та оволодіння академічним мовленням англійською мовою

У статті розглядаються лінгвістичні характеристики академічного мовлення англійською мовою. Докладно проаналізовані стилі, жанри та словниковий склад академічного мовлення англійською мовою. Крім того, досліджене питання використання словників у процесі навчання та оволодіння академічним мовленням англійською мовою. Встановлено типи словників, які застосовуються студентами вищих навчальних закладів на теперішньому етапі. Визначений ступінь відповідності макроструктурних та мікроструктурних якостей трьох типів словників, а саме: загальних словників, навчальних словників та словників для студентів університетів, освітнім потребам та інтересам суб'єктів навчання. Встановлено, що академічному мовленню англійською мовою властиві суттєві лінгвістичні відміннос- 
ті в залежності від приналежності до певної сфери дискурсу, жанру чи наукової галузі. Варіативність лексичного складу та застосовуваного граматичного інструментарію академічного мовлення англійською мовою зумовлює необхідність оволодіння студентами вищих навчальних закладів широким спектром мовних та мовленнєвих вмінь та навичок. Відтак для розвитку й удосконалення академічного мовлення англійською мовою учні потребують наявності спеціалізованих лінгвістичних засобів й інструментів, а саме словників, в яких повною мірою були б відображені специфічні риси академічного мовлення іноземною мовою.

Аналіз властивостей та якостей словників, які використовують студенти у навчальному процесі, засвідчує, що жоден з вищезгаданих типів словників не задовольняє повною мірою потреб, запитів та інтересів суб'єктів навчання. Як у загальних словниках, так і навчальних словниках та словниках для студентів університетів наводяться надмірно широкі пояснення, подаються складні лінгвістичні визначення, проте спеціалізована фахова інформація, що надається, не є вичерпною.

У статті вказується на необхідність створення словників, які б відповідали навчальним потребам студентів, які опановують академічне мовлення англійською мовою.

Ключові слова: академічне мовлення англійською мовою, словник, вивчення мови, жанри усного та письмового мовлення, навчання мови. 